MAREK JAWORSKI

Instytut Politologii UMK

\title{
Nova et Vetera. „Przedsoborowa” katolicka nauka społeczna w ujęciu wybranych nurtów we współcze- snym polskim katolicyzmie
}

Sobór Watykański II stanowił w zgodnej opinii komentatorów przełom w nauce społecznej Kościoła ${ }^{2}$. Charakter, zakres i głębokość owego przełomu stały się (i dalej stają) przedmiotem polemik w łonie katolicyzmu polskiego $^{3}$. W moim przekonaniu, pewnym wyznacznikiem opinii na temat głębokości przemian, jakich dokonał Sobór Watykański II, jest właśnie stosunek autorów chronologicznie „posoborowych” do „przedsoborowej” nauki społecznej Kościołaํ. Postaram się ukazać poglądy autorów należących do

'Już na wstępie należałoby zaznaczyć, że „katolicką naukę społeczną” będę w owym szkicu traktował szerzej niż czyni to choćby Czesław Strzeszewski, który ujmuje ją jako „naukę katolicką w odniesieniu do zagadnień społecznych i gospodarczych, do życia społecznogospodarczego" Katolicka nauka społeczna, Warszawa 1985, s. 157. Z uwagi na inny zakres przedmiotowy zagadnień, jakie będą mnie tu interesowały, chciałbym się skupić na ukazaniu recepcji takich elementów „przedsoborowej” katolickiej nauki społecznej jak wolność religijna, stosunki państwo - Kościół czy ogólnie problemy teologii politycznej.

2 Terminy: „katolicka nauka społeczna” i „nauczanie społeczne Kościoła” będę stosował zamiennie.

${ }^{3}$ Najbardziej widocznym stał się w tej kwestii casus Radia Maryja. Przeciwnicy tejże rozgłośni, pośród kierowanych w jej stronę zarzutów podnoszą problem jej "przedsoborowego" nastawienia, czy „nieakceptacji ducha Vaticanum II”. Por. J. Gowin, Kościót w czasach wolności, Kraków 1999, s. 382-390. Pojęcie „ducha Soboru” we współczesnym katolicyzmie budzi wielkie kontrowersje, o czym postaram się jeszcze wspomnieć.

${ }^{4}$ Przymiotniki owe ujmuję w cudzysłowy z uwagi na to, że w moim przekonaniu mają one, jeśli można tak rzec, charakter relatywny. Nie można, bowiem sztucznie dzielić nauczania 
najbardziej reprezentatywnych nurtów polskiego katolicyzmu (a także, jak sądzę, najbardziej interesujące). Nie zamierzam jednak podejmować próby odtworzenia stanowiska, jakie w tej materii zajmują autorzy skupieni wokół wspomnianego już Radia Maryja. Powód jest zasadniczy: nie zdołałem odnaleźć w ich tekstach szerszych odniesień do „przedsoborowej” nauki społecznej Kościoła ${ }^{5}$.

Wątki „przedsoborowego" nauczania społecznego występują w tekstach autorów związanych ze środowiskiem krakowskiego „Znaku” i „Tygodnika Powszechnego" z jednej strony, zaś z drugiej - w twórczości środowisk, które reprezentują katolicyzm, który nazwałbym integrystycznym. Jest on reprezentowany na łamach takich periodyków jak kwartalnik „Pro Fide, Rege et Lege” czy dwumiesięcznik „Christianitas”, a także „Fronda”.

Jako pierwszym chciałbym się przyjrzeć dwóm ujęciom omawianego problemu, dokonanym przez czołowych przedstawicieli środowiska „Znaku”: księdza Józefa Tischnera oraz Stefana Swieżawskiego. Poglądy obu tych filozofów kształtowały się w jawnej opozycji do idei propagowanych przez integrystów ${ }^{6}$. Zresztą zależność owa występowała także w kierunku przeciwnym. Józef Tischner „przedsoborową” naukę społeczną Kościoła widział przez pryzmat właśnie kurczowego trzymania się jej przez nurt integrystyczny. Współczesny, odrzucający społeczne nauczanie Vaticanum II integrysta jawi się krakowskiemu myślicielowi jako ten, „kto myśląc o wierze nie jest w stanie wyzwolić się od modelu władzy i panowania; integrystą jest ten, kto sakralizuje państwo i upaństwawia religię (...) ten, dla kogo godność człowieka opiera się na wyznawanej przez człowieka „prawdzie”(...). Integrystą jest ten, kto od krytyki liberalizmu, przechodzi natychmiast do ataku na wolność"' W W zasadzie nie ma w tekstach Tischnera sugestii, że integryści fałszowali „przedsoborowe” nauczanie społeczne Kościoła”, co dowodzi tezy, że w jego mniemaniu ich poglądy są w istocie (choć nie bez wyjątków) wiernym odbiciem idei obecnych w kościelnych dokumentach społecznych przed Soborem. Z tego zaś wypływa wniosek, nie wyrażony wprost przez Tischnera, że Sobór Watykański II w nauczaniu społecznym dokonał zasadniczego

Kościoła na przed- i po- soborowe, gdyż już takie zestawienie może nasuwać myśl, że Sobór stanowił jakąś doktrynalną cezurę w Kościele katolickim.

${ }^{5}$ Pomijam oczywiście ujęcia czysto podręcznikowe (np. o. Jana Mazura OSSPE, Katolicka nauka społeczna, Kraków 1992). Nie mogłem niestety dotrzeć do prac Stanisława Krajskiego poświęconych nauczaniu społecznemu Piusa IX, czy zagadnieniom filozofii społecznej i politycznej w katolicyzmie polskim w XX-leciu międzywojennym.

${ }^{6}$ Którzy z kolei identyfikują publicystów „Znaku” jako neomodernistów.

7 J. Tischner, W krainie schorowanej wyobraźni, Kraków, 1998, s. 188. Ujęcie owo ze strony właśnie integrystycznej zostało odczytane jako „karykaturalne”. Por. J. Bartyzel, Integryzm, dostępne: http://haggard w.interia.pl/jb.html [25.07.2006]. 
przełomu. Przełomu, ale jednak nie zerwania, jak uważają integryści ${ }^{8}$. W rozpoznaniu autora Etyki solidarności przełom ów polegał na wyakcentowaniu przez Sobór, zwłaszcza w Deklaracji o wolności religijnej, kwestii godności osoby ludzkiej'. Zdaniem Tischnera, przed Soborem katolicyzm ponad prawdę o godności każdego człowieka wysuwał swoiste „prawo prawdy”, czyli prawdziwej religii katolickiej. Przenosząc kwestię na teren polityczny, należałoby powiedzieć, że „przedsoborowe” nauczanie społeczne żywiło głęboką i umotywowaną doktrynalnie niechęć do liberalnej demokracji, przy jednoczesnej sympatii dla autorytarnych form sprawowania władzy. Demokracja bowiem nie znajdywała żadnej różnicy pomiędzy ideami czy doktrynami religijnymi wyznawanymi przez obywateli i przez nich swobodnie głoszonymi (na tym m.in. polega gwarantowane przez konstytucje państw demokratycznych prawo do wolności religii). Wobec tego w państwie demokratycznym fałszywe (czyli różne od katolickiej) doktryny religijne mogły być głoszone na równi z religią katolicką, a sam Kościół często posiadał tylko prawa przysługujące innym wspólnotom religijnym ${ }^{10}$. Państwo demokratyczne nie dawało Kościołowi żadnych przywilejów i nie spełniało roli, jaką przed Soborem wyznaczał państwu Kościół. Miało być ono imperium felix w rozumieniu św. Augustyna, czyli państwem, którego polityka, ma służebny charakter w stosunku do zbawczego posłannictwa Kościoła. „Tron” winien więc na przykład ograniczać głoszenie doktryn religijnych czy filozoficznych, które "Ołtarz" uważa za zagrażające zbawieniu dusz rzymskich katolików. Wiązał się z tym negatywny stosunek Kościoła do wolności religijnej. Państwo bowiem, co powtarzali wielokrotnie „przedsoborowi” papieże, winno aktywnie wspierać prawdziwą religię objawioną tj. katolicką, a inne kulty co najwyżej tolerować $\mathrm{w}$ imię zachowania pokoju społecznego i uniknięcia większego zła, jakim mogłyby być wojny religijne ${ }^{11}$. Zdaniem

${ }^{8}$ Por. A. Wielomski, Teologia polityczna Soboru Watykańskiego II, http://www.konserwatyzm.pl/ [25.07.2006].

9 Por. J. Keller, Katolicka doktryna społeczna, Warszawa 1989, s. 201-202.

${ }^{10}$ Taki stan rzeczy zaistniał choćby we Francji po roku 1906, czyli po ustawie sankcjonującej rozdział państwa i Kościoła. Zresztą właśnie dzieje katolicyzmu francuskiego z oczywistych historycznych powodów wpływały na „przedsoborową” niechęć Kościoła do liberalnej demokracji.

${ }^{11}$ Najważniejsze dokumenty Magisterium w tym względzie to: encyklika Quanta cura Piusa IX wraz z dołączonym do niej słynnym Syllabusem oraz encykliki Leona XIII: Immortale Dei i Libertas. Ważne są także dokumenty papieża Grzegorza XVI, jak choćby encyklika Mirari vos. Por. J. Keller, Katolicka..., s. 192. Warto jeszcze dodać, że w realiach dwudziestowiecznych w państwach o większości niekatolickiej Kościół domagał się wolności dla siebie, nie wymagając w tejże sytuacji od państwa ograniczania wpływów religii niekatolickich. Nie była to, co ciekawe, zmiana doktryny, lecz jedynie jej aplikacja do konkretnej sytuacji społecznoreligijnej. Por. E. W. Böckenförde, Wolność, państwo, Kościót, Kraków 1994, s. 54-55. Także: J. Tischner, $W$ krainie..., s. 19-20. 
Tischnera, przejście od negacji wolności religijnej do jej afirmacji dokonało się w Kościele drogą zasady godności osoby ludzkiej. „Sobór - pisze Tischner - argumentuje następująco: między prawdą a fałszem zachodzi oczywiście istotna różnica. Nie ma jednak różnicy między godnością człowieka błądzącego a godnością człowieka żyjącego w prawdzie. Skoro godność jest taka sama, prawa człowieka - prawa każdej religii winny być równe"12. Akceptację wolności religijnej przez Sobór Watykański II widział krakowski myśliciel w szerszym kontekście akceptacji przez współczesny katolicyzm doktryny praw człowieka. Warto jednak zapytać: jak dokładniej Tischner ujmował ów przełom w nauczaniu społecznym dokonany przez Sobór? Czy wprost zgadzał się z tezą, że nauczanie „przedsoborowych” papieży, choćby na temat wolności religijnej czy państwa katolickiego, po prostu się zdezaktualizowało $^{13}$ ? Filozof wprost takiego poglądu nie wypowiada, można jednak domniemywać, że w pewnym szczególnym sensie się z nim zgadzał. Jak sądzę kluczem jest tu rozumienie Tradycji w Kościele Katolickim. Józef Tischner krytykował i wprost odrzucał ujęcie Tradycji, jakie prezentował abp M. Lefebvre ${ }^{14}$. „Tradycja - pisze Tischner - oznacza drogę «dojrzewania prawdy». Droga dojrzewania prawdy nie jest poza prawdą, lecz jest częścią prawdy (...). Kto chce wiedzieć, co znaczą prawa człowieka, musi uwzględnić także historię praw człowieka. W historii tej napotka również krytykę idei praw człowieka przez papieży. Wtedy jednak nie trzeba odwracać głowy od krytyki, lecz pójść głębiej i pytać, czego naprawdę krytyka ta dotyczyła i czy przypadkiem nie odegrała pozytywnej roli w krystalizowaniu się tego pojęcia. Idea tradycji wspiera się na dwóch zasadach: mimo relatywizmu dziejów nie wszystko jest w nich relatywne, mimo wieczności prawdy jej rozumienie dokonuje się w czasie"15. Tischnerowskie rozumienie Tradycji, jak sądzę jest po części inspirowane hermeneutyką, głównie w ujęciu H. G. Gadamera ${ }^{16}$. Prawda, według tego ujęcia, objawiona zostaje człowiekowi z uwzględnie-

\footnotetext{
${ }^{12}$ J. Tischner, $W$ krainie..., s. 171. Ze strony integrystów podnoszono tu zarzut że Sobór pominął rozróżnienie między godnością początkową (opartą na rozumie i wolnej woli) a godnością ostateczną, opierającą się na życiu człowieka w stanie łaski Bożej. Por. M. Lefebvre, Oni Jego zdetronizowali. Od liberalizmu do apostazji. Tragedia soborowa, Warszawa 1997, s. 175.

${ }^{13}$ Tezę taką głosił choćby Jacques Maritain, czołowy chyba prekursor społecznego przesłania Soboru. Inni teologowie, (J. Murray, R. Aubert), twierdzili natomiast, że papieże zareagowali zbyt gwałtownie, że potępienia były spowodowane ówczesną sytuacją papiestwa. Por. M. Lefebvre, Oni Jego zdetronizowali..., s. 75. Por. także: W. Szukalski, od tolerancji do wolności religijnej. Ewolucja pogląów w dokumentach Soboru Watykańskiego II, Poznań 2003, s. 8-9.

${ }^{14}$ Niestety wypowiedzi autora Etyki solidarności nie przywołują konkretnych tekstów arcybiskupa.

${ }^{15} \mathrm{~J}$. Tischner, $W$ krainie..., s. 199. Pomijam tu bezpośrednią krytykę poglądów Lefebvre’a właśnie z powodu braku rzetelnych odniesień do jego tekstów w tej materii.

${ }^{16}$ Por. J. Tischner, Ksiądz na manowcach, Kraków 1999, s. 161.
} 
niem historyczno-kulturowych realiów, w jakich się znalazł. Nie oznacza to, że zmienia się prawda. Nie, zmienia się tylko i pogłębia jej rozumienie. Przekładając owe ujęcia na kwestie nauczania społecznego XIX-wiecznych papieży, należałoby chyba, rekonstruując poglądy Tischnera, stwierdzić: papieże XIX wieku rozumieli prawdę o wolności religijnej czy o prawach człowieka w sposób, w jaki ukazała im się poprzez dzieje ówczesnego laicyzmu i gwałtownie antykatolickiego liberalizmu. Nie znaczy to, że ich ujęcie było błędne, czy zbyt gwałtowne. Było na miarę ich ówczesnego rozumienia rzeczywistości społecznej. Z tej więc pozycji absurdem jest krytyka choćby słynnego syllabusa. Był on bowiem, jak i inne XIX-wieczne dokumenty, niezbędny. Sobór Watykański II, zdaniem Tischnera, pogłębił rozumienie wolności religijnej, zobaczył ją bowiem z innej perspektywy dziejowej, przede wszystkim z perspektywy dwudziestowiecznych totalitaryzmów ${ }^{17}$. Komentując poglądy Tischnera w kwestii Tradycji warto, jak sądzę, wskazać kilka ogólniejszych problemów w kwestii natury katolickiej nauki społecznej i jej XX-wiecznej ewolucji. Tak o tym pisze Czesław Strzeszewski: „Stąd poczynając od encykliki Mater et Magistra Jana XXIII nauka społeczna podlega ewolucji od charakteru doktrynalnego do pastoralnego. Zostają w niej wskazane ogólne zasady społeczno-moralne, natomiast co się tyczy zagadnień szczegółowych, to mamy więcej wskazań negatywnych tj. przestrzegających przed odejściem od zasad chrześcijańskiej moralności społecznej (...). Wskazania pozytywne mają charakter rady, a nie nakazu ${ }^{18}$. Jak sądzę wynikało to także z uznania przez Sobór autonomii rzeczywistości ziemskich"19.

Jako krótkie podsumowanie poglądów Tischnera na relacje między preconsilium i postconsilium w nauczaniu społecznej Kościoła, powiedzieć trzeba, że ustrzegł się on traktowania Soboru jako historiozoficznej przepaści, dzielącej kościół na „przedsoborowy” i „posoborowy” i co za tym idzie, gloryfikacji tego drugiego przy deprecjonowaniu pierwszego ${ }^{20}$.

Niestety, błędu owego nie ustrzegł się kolejny ważny autor w środowisku „Znaku” - Stefan Swieżawski. Podczas Soboru był on jedynym jego

\footnotetext{
${ }^{17}$ Nie będę rozwijał tu szerzej analizy poglądów Tischnera na kwestie hitleryzmu czy komunizmu.

${ }^{18} \mathrm{Cz}$. Strzeszewski, Katolicka..., s. 167. Zapewne wiąże się z tym kwestia ogłoszenia Soboru Watykańskiego II pastoralnym.

${ }^{19}$ Por. Gaudium et spes, 36, w: Sobór Watykański II, Konstytucje, deklaracje, dekrety, Poznań 1968, s. 563. Także J. Tischner, $W$ krainie..., s. 74. Ciekawą jest rzeczą, że główny teoretyk integryzmu w swej podstawowej pracy poświęconej Soborowi w jego społecznym wymiarze nie wspomina o naturze społecznej nauki Kościoła. Daje się za to zauważyć tendencję do jej dogmatyzacji. Por. M. Lefebvre, Oni Jego zdetronizowali..., passim.

${ }^{20}$ Co z resztą, przy odwróconym ujęciu, łączy lefebrystów z radykalnymi progresistami czy modernistami. Por. P. Milcarek, Religia demokracji, „Christianitas”, nr 25, 2006, s. 144.
} 
audytorem z obszaru państw komunistycznych. W swej działalności filozoficznej sferą polityki się nie zajmował, toteż jego poglądy na interesującą mnie tu kwestię ujawniał jedynie wyjątkowo i w sposób stricte publicystyczny. Jednak zapatrywania Swieżawskiego na relacje między „przedsoborową" a "posoborową" nauką społeczną Kościoła wydają mi się w pewien sposób reprezentatywne (bardziej niż Tischnera) dla środowiska "Znaku”. Swieżawski wychodzi z założenia, że epoka „przedsoborowa” w Kościele to „era konstantyńska”. Polegała ona (od czasów Edyktu Mediolańskiego) na sojuszu „tronu i ołtarza”, a więc na koncepcji państwa służebnego wobec Kościoła Katolickiego. Dopiero zaś Sobór Watykański II zerwał jednoznacznie z ową teorią i praktyką. „Na Soborze - powiada Swieżawski - mówiło się, że trzeba skończyć z epoką konstantyńską. Ona się na szczęście skończyła; Kościół stracił swoje państwo, stracił straszliwe obciążenie polityczne, które się z nim łączyło oraz całą fałszywą ambicję teokratyzmu, tzn. bezpośredniej władzy w porządku doczesnym. Skończył się także absolutny monarchizm papieski ${ }^{21}$. Nie sposób nie zauważyć, że znany mediewista nie tylko upraszcza, ale i miesza pojęcia. „Absolutny monarchizm papieski”, o którym mówi profesor, występował czy raczej „próbował występować” w dojrzałym średniowieczu za pontyfikatów choćby Grzegorza VII czy Innocentego III. Z tymi postaciami należałoby wiązać owe „teokratyczne” ambicje papieży ${ }^{22}$. Trudno więc zrozumieć pogląd Stefana Swieżawskiego, że „teokracja papieska" miałaby się skończyć na Soborze Watykańskim II. W nauczaniu społecznym papieży wyraźnie została wyartykułowana teza o władzy pośredniej Kościoła nad władzami świeckimi. Ingeruje on w sprawy państwowe tylko, gdy $\mathrm{w}$ grę wchodzą kwestie religijne i moralne, wiążące się ze zbawieniem dusz ${ }^{23}$. Nauczanie społeczne Soboru Watykańskiego II interpretuje Swieżawski także jako koniec ery Christianitas - wspólnoty chrześcijańskich państw w Europie. „Paweł VI - powiada - widział zaś wyraźnie słuszność Maritainowskiej koncepcji całego humanizmu integralnego. Chodzi o to, że nie ma absolutnie sensu w jakikolwiek sposób odnawianie średniowiecznego pojęcia christiani-

${ }^{21}$ T. Królak, Kontemplacja i zdradzony świat. Rozmowy z prof. Stefanem Swieżawskim, Poznań 1999, s. 159.

${ }^{22}$ Jeśli jednak przez „teokrację” rozumieć będziemy rządy kapłańskie, to wymienieni papieże nie chcieli przecież likwidować państw (monarchii) i rządzić samodzielnie i niepodzielnie. „Wydaje się - pisze Jacek Bartyzel - że jest to [teokracja - M.J.] określenie dalekie od ścisłości. Zważywszy, że nawet najdalej idące roszczenia papieży tego okresu [średniowiecza - M.J.] ujmowane były w kategoriach typowych dla świeckich ujęć prawnych tej epoki tj. feudalizmu (...). Nie oznaczały tedy dążenia do zatarcia dualizmu dwóch państw - Bożego (Civitas Dei) i ziemskiego (Civitas terrena)" - J. Bartyzel, Teokracja, dostępne: http://haggard.w.interia.pl/jb.html [25.07.2007].

${ }^{23}$ Autorem tej koncepcji był Akwinata a do nauczania pontyfikalnego szerzej wprowadził ją w swoich encyklikach Leon XIII. 
tas. (...) Trzeba uznać społeczeństwo takie, jakim jest i tak działać jak pierwsi chrześcijanie, to znaczy w niechrześcijańskiej społeczności” ${ }^{24}$. Poglądy filozofa oddają chyba jednak nie „literę" Vaticanum Secundum, ale jego mglistego „ducha”. Koniec ery Christianitas nie musi przecież oznaczać końca chrześcijańskiego społeczeństwa ${ }^{25}$. Swieżawski niejako „namawia” chrześcijan, by trwale przystosowali się do życia w świecie niechrześcijańskiej większości. Zwraca jednak uwagę następujący fakt: chrześcijanie pierwszych wieków, na których „posoborowy” katolicyzm często się powołuje, nie zakładali, że już na zawsze będą egzystować jako mniejszościowa „sekta” w Imperium Romanum. Przeciwnie, dokonali chrystianizacji tego imperium ${ }^{26}$. Swieżawski jest wyraźnie zapatrzony w „posoborowy” katolicyzm francuski, który faktycznie stał się we Francji niemal marginalny. Absurdem jest jednak uważanie takiego modelu obecności katolicyzmu we współczesnym świecie za jakiś obowiązujący wzór. Oczywiście, trudno tu wskazywać na kryterium ilościowe. Nie można dowodzić, że dane społeczeństwo jest bardziej katolickie niż inne, posługując się tylko danymi statystycznymi. Swieżawski jednak całkowicie pomija wpływ katolicyzmu na życie społeczno-polityczne ${ }^{27}$. Nic zresztą w tym dziwnego, skoro „Kościół nie ma być Kościołem sukcesu, tylko Kościołem świadectwa. Sukces, nawet duchowy, nie jest żadnym celem w Kościele" ${ }^{28}$.

„Przedsoborowa” nauka społeczna w interpretacji ks. Józefa Tischnera i Stefana Swieżawskiego ma jednak, w interesujących mnie tu aspektach, charakter mimo wszystko nieadekwatny do „posoborowej” rzeczywistości. Obaj autorzy, mimo dzielących ich różnic, wskazują na duży pozytywny ładunek zawarty w „posoborowym” nauczaniu społecznym. Swieżawski, choć bez szerszych analiz, nauczanie przed Soborem zdaje się traktować negatywnie, a Sobór widzi jako wręcz „kopernikańską” rewolucję w doktrynie społecznej Kościoła.

Co ciekawe, o czym już poniekąd wspominałem, w pewnym sensie analogiczne ujęcie prezentuje integrystyczny nurt współczesnego polskiego katolicyzmu. Integryzm owego nurtu identyfikowałbym jako krytyczne nastawienie zarówno do nauczania społecznego Soboru, jak i do doktryny

\footnotetext{
${ }^{24}$ T. Królak, Kontemplacja..., s. 166-167.

${ }^{25}$ Por. V. Possenti, Katolicka nauka spoleczna wobec dziedzictwa oświecenia, Kraków 2000, s. 248.

${ }^{26}$ Pomijam tu dywagacje na temat pozytywów i negatywów owej chrystianizacji. Faktem pozostaje jednak, że dokonała się i to w niecałe cztery wieki.

${ }^{27}$ Być może uważałby ten wpływ za powrót „ery konstantyńskiej”?

${ }^{28}$ S. Swieżawski, Lampa wiary, Kraków 2000, s. 29-30. Oczywiście sukcesu Kościoła nie należy pojmować w kategoriach „marketingowych” (i w tym sensie ma Swieżawski rację), ale skupienie się tylko na dawaniu świadectwa, a pomijanie głębokiej reewangelizacji Europy i świata, to niedopuszczalny minimalizm i, jak sądzę, wpływ mętnego „ducha Soboru”.
} 
społecznej papieży Jana XXIII i Pawła VI ${ }^{29}$. W warstwie pozytywnej zaś przynależący do tego nurtu trzymają się ściśle „przedsoborowego” nauczania społecznego. Jak już wcześniej wspomniałem, najważniejsze pojawiające się tu zagadnienia to: relacja państwo - Kościół, wolność religijna czy ogólnie problemy teologii politycznej. W tekstach "katolików integralnych" odnaleźć można tezę, że w powyższych kwestiach nauczanie „posoborowe” radykalnie zerwało z nauczaniem „przedsoborowym" ${ }^{30}$. Pierwszą sprawą, na którą, jak sądzę, warto tu zwrócić uwagę, jest porzucenie przez Sobór tradycyjnej koncepcji „państwa katolickiego”. Dokonało się ono głównie w soborowej Deklaracji o wolności religijnej, która stwierdza w jednym z kluczowych zdań: „Obecny Sobór Watykański oświadcza, że osoba ludzka ma prawo do wolności religijnej. Tego zaś rodzaju wolność polega na tym, że wszyscy ludzie powinni być wolni od przymusu, czy to poszczególnych ludzi, czy zbiorowisk społecznych i jakiejkolwiek władzy ludzkiej, tak aby w sprawach religijnych nikogo nie przymuszano do działania wbrew jego sumieniu, ani nie przeszkadzano mu w działaniu według swego sumienia" ${ }^{31}$. Integryści widzą w owym soborowym dokumencie akceptację zasady libre examen (swobodne badanie). Człowiek, według Soboru, może własnym rozumem badać poszczególne doktryny religijne i wybrać tę, którą w swoim sumieniu uzna za prawdziwą ${ }^{32}$. Jest to w rozpoznaniu integrystów jawne zerwanie z nauczaniem XIX-wiecznych papieży, wprost odrzucających wolność religijną ${ }^{33}$. Według nauczania soborowego państwo nie powinno swoim aparatem przymuszać kogokolwiek do wyznawania bądź niewyznawania jakiejkolwiek religiii ${ }^{34}$. Państwu nie przysługuje także prawo do badania, która religia jest prawdziwa i nie ma obowiązku wyznawania jej. O ile papieże „przedsoborowi”

\footnotetext{
${ }^{29}$ Charakterystyczne jest, że w tekstach integrystów (ale związanych, z Bractwem św Piotra) nie ma krytyki nauczania społecznego Jana Pawła II. Zapewne znalazłaby się ona w tekstach autorów związanych z Bractwem św. Piusa X (lefebrystów). Analizy ich poglądów nie będę jednak podejmował, bo $\mathrm{w}$ zasadniczych punktach jest ono zgodne $\mathrm{z}$ ujęciami autorów przywiązanych do "przedsoborowego" katolicyzmu, ale z Bractwem św. Piusa X niezwiązanych. Por. J. Bartyzel, Problemy teologii politycznej w koncepcjach wspótczesnych kierunków myśl prawicowej na Zachodzie, w: Religia chrześcijańska a idee polityczne, B. Grott (red.), Kraków 1998, s. 130-131.

${ }^{30}$ Por. A. Wielomski, Teologia polityczna Soboru Watykańskiego II, http://www.konserwatyzm.pl/ [25.07.2006].

${ }^{31}$ Deklaracja Dignitatis humanis, w: Sobór Watykański..., s. 415.

${ }^{32}$ Por. A. Wielomski, Dezintegracja kontrrewolucji hiszpańskiej w kontekście nauczania Soboru Watykańskiego II. Referat wygłoszony 15.09 .2005 na konferencji Panorama myśli kontrrewolucyjnej na UMK w Toruniu.

${ }^{33}$ Papież Pius IX potępił w Syllabusie zdanie: „Każdy człowiek ma swobodę przyjęcia i wyznawania takiej religii, jaką uzna za prawdziwą, kierując się światłem rozumu", cyt. za: J. Keller, Katolicka doktryna..., s. 193. Por. też: M. Lefebvre, Oni Jego zdetronizowali..., s. 71-80.

${ }^{34}$ Por. Dignitatis humanae 6.
} 
uczyli, że państwo winno katolicyzm (religię prawdziwą) uczynić religią uprzywilejowaną, to po Soborze takiego obowiązku już nie $\mathrm{ma}^{35}$. Według przedstawicieli nurtu integrystycznego soborowa nauka zbliża się niebezpiecznie w stronę optymistycznej antropologii liberalnej. Oto bowiem w nauczaniu tradycyjnym człowiek, by zwrócić się w stronę prawdy, jako istota skażona grzechem pierworodnym musiał podlegać pewnemu przymusowi ${ }^{36}$. Natomiast Sobór, przeciwnie, w Dignitatis humanae mówi, miast o ochronie katolicyzmu, o wolności religijnej i wolności sumienia.

Komentując poglądy integrystów, zauważyć jednak wypada, że nie są one zgodne z kościelnym nauczaniem „posoborowym”. Istotnie, papieże przed Soborem twierdzili, że wolność religijna konstytuuje $\mathrm{w}$ istocie indyferentyzm religijny, a więc zagubienie prawdziwości katolicyzmu. Jednak Katechizm Kościoła Katolickiego, wydany kilkadziesiąt lat po Soborze, w paragrafach 2108 i 2103 na ten temat mówi m.in.: „Prawo do wolności religijnej nie oznacza moralnej zgody na przylgnięcie do błędu ani rzekomego prawa do błędu - lecz naturalne prawo osoby ludzkiej do wolności cywilnej, to znaczy, w słusznym zakresie, do wolności od przymusu zewnętrznego w sprawach religijnych ze strony władzy politycznej (...). Prawo do wolności religijnej nie może być w sobie ani nieograniczone ani ograniczone tylko przez «porządek publiczny» pojmowany w sposób naturalistyczny lub pozytywistyczny" ${ }^{37}$. Osobiście w kwestii soborowej wolności religijnej postawiłbym następującą hipotezę: być może jej proklamowanie dało Kościołowi jasne, doktrynalne przesłanki do walczenia o wolność dla mniejszości katolickiej, na przykład w krajach islamskich. Przed Soborem owych przesłanek nie posiadał (przynajmniej w formie, która mogłaby być zaakceptowana przez niekatolików), a doktryna tolerancji Piusa XII, to jednak za mało ${ }^{38}$. Je-

${ }^{35}$ Choć dopuszczalna jest sytuacja, by pewnej religii (a więc i katolicyzmowi) przyznać uprzywilejowaną pozycję, nie naruszając przy tym praw innych religii.

${ }^{36}$ Oczywiście, nie chodzi o zmuszanie kogokolwiek do przyjęcia wiary katolickiej, ale o to, że państwo powinno, posługując się swoim ustawodawstwem, jej przyjęcie ułatwić, m.in. przez ograniczanie wpływu doktryn akatolickich i antykatolickich (oczywiście na miarę możliwości i roztropności).

${ }^{37}$ Katechizm Kościoła Katolickiego, Poznań 1994, s. 485. Co ciekawe, w przypisach do tychże punktów obecne są także dokumenty papieskie, potępiające wolność religijną (encyklika Libertas Leona XIII czy Quanta cura Piusa IX). W ogóle można odnieść wrażenie, że Katechizm usiłuje znaleźć punkt wspólny pomiędzy nauczaniem „przedsoborowym” a „posoborowym” oraz przeciwstawić się ujęciom zrywającym tę ciągłość. Choć pozostaje faktem, że w tekście Dignitatis humanae brak przypisów odwołujących się do wcześniejszych dokumentów pontyfikalnych, poruszających problem wolności religijnej.

${ }^{38}$ Por. M. Buszewski, Quo vadis Econe?, „Pro Fide, Rege et Lege”, nr 2(55), s. 47. Także: N. Koshy, Wolność religijna w zmieniajacym sie świecie, Kraków 1998, s. 147-150. Czasem podnosi się także kwestię rozwoju i przemian w doktrynie praw człowieka i liberalizmie. W XX. wieku bowiem laicyzm państwowy nie musi być już tak groźny dla Kościoła, jak w XIX w. i dlatego 
żeli temat „państwa katolickiego” chciałoby się przedstawić w szerszej nieco perspektywie, należałoby przejść do omówienia, choćby pobieżnego, przemian w katolickiej teologii politycznej. Pomijając spory definicyjne, uznajmy teologię polityczną za refleksję nad polityką, wspierającą się nie tylko argumentami rozumu, ale i argumentami wiary. Zdaniem więc integrystów, zerwanie ciągłości doktrynalnej dokonane przez Sobór objawiło się najwyraźniej w sekularyzacji katolickiej teologii politycznej. Kościół nie oczekuje już od państw aktywnego wsparcia jego zbawczej misji. „Urząd Nauczycielski - pisze Jacek Bartyzel - nie oczekuje już od państwa i piastunów władzy realizacji Społecznego Królestwa Jezusa Chrystusa (...). Oznacza to, że hierarchia Kościoła "posoborowego» nie tylko pogodziła się z faktem istnienia państw laicko-liberalnych, ale uznała za słuszną i godziwą samą koncepcję państwa demoliberalnego (bezwyznaniowego), od którego oczekuje już jedynie zwykłej dla stowarzyszeń dobrowolnych przestrzeni wolności dla swojej posługi duszpasterskiej” ${ }^{39}$. Kościół został więc niejako „pokonany” przez Rewolucję Francuską, dostosowując się na Soborze do jej dyrektyw. Owo dostosowanie zostało określone jako aggiornamento, którego inaczej jeszcze wyrażonym politycznym następstwem jest „pojawienie się w nowym nauczaniu kategorii Praw Człowieka, wywodzącej się z antropologii laickoliberalnej, choć oczywiście podejmowany jest wysiłek uzgadniania tych praw $\mathrm{z}$ tradycyjną doktryną prawa naturalnego, czy nawet ich wyprowadzania stamtąd, w czym pomocna miała być jak wiadomo tzw. teoria personalistyczna, głównie w ujęciu Maritaina. Antropocentryczny personalizm zdominował do tego stopnia współczesny język eklezjalny, że wypełnił także nieomal sferę opisu natury wspólnoty politycznej oraz listę postulatów zgłaszanych pod jej adresem. Wspólnota polityczna jest już definiowana wyłącznie $\mathrm{w}$ aspekcie doczesno-horyzontalnym, jako wspólnota obywatelska, a zatem w zgodzie z dyskursem demoliberalnym, korygowanym jedynie z punktu widzenia ochrony Praw Człowieka, przy całkowitym milczeniu o prawach Boga i obowiązkach wspólnoty politycznej wobec Niego" ${ }^{40}$. Wedle powyższego ujęcia głównym czynnikiem demontującym tradycyjną teologię polityczną stało się przyswojenie przez katolicyzm liberalnej koncepcji Praw Człowieka. Oczywiście, dla państwa katolickiego, a raczej dla jego upadku, decydujące

\footnotetext{
katolicyzm mógł na pewnych warunkach „pojednać się” z demokracją liberalną. Nie będę jednak rozwijał tego problemu.

${ }^{39} \mathrm{~J}$. Bartyzel, Katolicka teologia polityczna w XX wieku, dostępne: http://haggard.w.interia.pl/jb.html [25.07.2007]. Owa przestrzeń wolności dla Kościoła wygląda chyba jednak nieco inaczej w poszczególnych państwach (inaczej w Polsce niż choćby w Hiszpanii). Wynika to zapewne nie tylko z uwarunkowań prawnych (konkordat), ale i ze specyficznej dla każdego kraju sytuacji politycznej.

${ }^{40}$ Tamże.
} 
znaczenie miało prawo do wolności religijnej (vide: Hiszpania), cała jednak doktryna Praw Człowieka (przed Soborem de facto potępiana) jest właściwym winowajcą sekularyzacji nowożytnej wspólnoty politycznej.

Jako podsumowanie niniejszego wątku chciałbym przedstawić pewną syntezę „przedsoborowego" nauczania na temat relacji państwa do Kościoła w ujęciu Jacka Bartyzela: „Generalnie całą tradycyjną naukę Kościoła, od Ojców Starożytnych po „epokę Piusów”, ująć można w następujące zasady prawa publicznego Kościoła: 1. Suwerenność i niezależność Kościoła, jako społeczności doskonałej i wspomaganej przez Jego Boskiego Założyciela, której celem jest nadprzyrodzone zbawienie dusz; 2. Odrębność Kościoła i państwa, będącego również społecznością doskonałą, suwerenną w swojej dziedzinie; której bezpośrednim celem jest współczesne dobro doczesne. Tę odrębność państwa papież Pius XII nazywa „prawomocną i zdrową świeckością", różną wszelako od laicyzmu; 3. Związek między Kościołem a państwem, którego podstawą winna być jednomyślność działania dla przyrodzonego i nadprzyrodzonego dobra człowieka; 4. Pośrednia jurysdykcja Kościoła nad doczesnością, dająca mu prawo do interwencji w sprawach doczesnych, które normalnie podlegają jurysdykcji państwa, z powodu grzechu i ze względu na zbawienie dusz; 5. Pośrednie podporządkowanie państwa Kościołowi, rozumiane jako zasada wiary lub przynajmniej teologicznej pewności, że cele realizowane przez państwo służą osiąganiu przez ludzi zbawienia; 6 . Służebna funkcja państwa, które winno wspierać Kościół we wszystkim, co służy osiąganiu jego zbawczego celu; 7. Społeczne panowanie Chrystusa Króla nad wszystkimi jednostkami i społeczeństwami, które domaga się przesycenia ustawodawstwa państwowego prawem Bożym w ten sposób, aby w swej (doczesnej) dziedzinie było ono instrumentem zbawienia dokonanego przez Chrystusa"41.

Warto jednak nadmienić, że owe zasady były przez papieży XIXwiecznych (aż do Piusa XII, dokładniej biorąc) ujmowane jako pewne szczeble do osiągnięcia stanu idealnego. Oprócz bowiem katolickiej większości w państwie, potrzebna była jeszcze chęć współdziałania ze strony władz państwowych. Ogółem należy stwierdzić, że zerwanie z tradycyjnym nauczaniem przez Sobór integryści oceniają negatywnie. Uważają, że Kościół skapitulował przed współczesnym, liberalnym światem. Zaakceptował bowiem oświeceniową doktrynę Praw Człowieka (choć nie bezwarunkowo), poprzez zadekretowanie wolności religijnej porzucił ideał państwa katolickiego; dokonał także akceptacji demokracji liberalnej, jako najlepszej formy

\footnotetext{
${ }^{41} \mathrm{~J}$. Bartyzel, Dwa miecze. Relacja Kościót - państwo w tradycyjnym nauczaniu i dziejach Christianitas, dostępne: http://haggard.w.interia.pl/jb.html [25.07.2007].
} 
ustrojowej ${ }^{42}$. Częściowo ową kapitulację Kościoła można wyjaśnić dostosowaniem języka Magisterium do współczesnego mu świata ${ }^{43}$.

Wartą podkreślenia (choćby pobieżnego) jest próba wskazania recepty na kryzys w sferze nauczania społecznego, toczący współczesny katolicyzm. Otóż ważne pole działania ma tutaj zaangażowany politycznie laikat katolicki. To jemu przypada więc rola „reteizacji” wspólnoty politycznej, przesycenia jej pierwiastkami tradycyjnego nauczania społecznego, które wszak nie zostało odwołane ${ }^{44}$.

Wszystkie przedstawione tu przeze mnie, nader co prawda pobieżnie, opcje zgadzają się co do faktu, że Sobór Watykański II stanowił ważne, wręcz najważniejsze, wydarzenie w katolicyzmie współczesnym. Interpretacja nauki „przedsoborowej”, jej stosunku do „posoborowej”, mówi zawsze wiele o pomysłach czy wizjach poszczególnych autorów co do kształtu Kościoła w świecie jednak ,p posoborowym”.

M A R E K J A W O R S K I

\footnotetext{
${ }^{42}$ Trzeba tu nadmienić, że Jan Paweł II wskazał wyraźnie, że Kościół nie dokonał „kanonizacji” demokracji i że inne ustroje państwowe pod pewnymi warunkami także są dopuszczalne. Por. Jan Paweł II, Pamięć i tożsamość, Kraków 2005, s. 135-136. Praca owa nie stanowi oczywiście nauczania magisterialnego, ale wyrażony w niej przez papieża pogląd na temat demokracji jest z pewnością ortodoksyjny. Por. Katechizm Kościoła Katolickiego..., s. 441.

${ }^{43}$ Por. J. Bartyzel, Katolicka teologia...

${ }^{44}$ Nawiasem mówiąc, te środowiska katolickie, które deklarują przywiązanie do katolicyzmu „przedsoborowego", akcentują także próbę uchwycenia ciągłości między nauczaniem „przedsoborowym” a „posoborowym”. Por. Nie uważam się za tradycjonalistę. Jestem po prostu katolikiem. Wywiad z ks. J. Bisigiem, przełożonym generalnym Bractwa św. Piotra, „W drodze”, nr 1, 1999, s. 19-30.
} 


\section{Nova et Vetera - selected streams of contemporary Polish catholicism towards "pre- conciliar" catholic church's social doctrine}

According to all commentators the Second Ecumenical Council of the Vatican was a break in Catholic Church's social doctrine. The importance of this break has became a battleground within the bosom of Polish Catholic Church. Attitude of postconciliar authors to pre-conciliar social doctrine of Church is indicated from the most representative authors' of all Polish Catholic streams opinions. Since such threads are hard to find in texts of Radio Maryja's authors, this analysis does not include them.

Pre-conciliar threads can be found in authors' connected with Cracovian "Znak" and "Tygodnik Powszechny" articles. But on the other hand they can be traced in texts written in milieu that could be called "integralist" - in periodicals such as "Pro Fide, Rege et Lege", "Christianitas" and "Fronda".

I try to outline Józef Tischner and Stefan Swieżawski's opinions - they both have very positive attitude towards the Second Vatican Council. The difference between them is their attitude to the pre-conciliar Church. Swieżawski is very negative about it while Tischner does not depreciate it. In my description of integralism stream I focus on matters that are pointed by this stream itself as "problematic", inter alia: religious freedom or human rights. But I also put emphasis on Catholic political theology secularisation, which (according to integralists) had been taking place and which resulted in laic-liberal arrangements of the Second Vatican Council.

Vision of this important (maybe even the most important) event in modern Christian history indicates author's visions and opinions on the role of the Church in modern world - world that indeed is post-conciliar. 